\title{
Proterozoic intracontinental basin: The Vindhyan example
}

\author{
Chandan Chakraborty \\ Geological Studies Unit, Indian Statistical Institute, 203 B.T. Road, Kolkata 700 108, India. \\ e-mail: chandan@isical.ac.in
}

The Vindhyan basin is a classic example of Proterozoic intracontinental basin that developed in the central part of the Indian shield along with several other basins such as Cuddapah, Chattisgarh, etc. The strata are exposed in three major sectors: Son valley, Bundelkhand and Rajasthan. Substantially thick Vindhyan rocks have also been recognized under the Gangetic alluvium. The constituent stratigraphic units of the Vindhyan Supergroup are laterally correlatable and vertically stacked in similar fashion in individual sectors, but their stratigraphic and sedimentologic attributes vary from one sector to the other. The basin fill in the Son valley (around $3 \mathrm{~km}$ thick) exhibits an asymmetric cross-sectional geometry normal to the regional strike (ENE-WSW), with the thickest part occurring to the south, and is divisible into four groups: Semri, Kaimur, Rewa and Bhander, from bottom to top. The boundary between the Semri and Kaimur Groups is marked by a pronounced unconformity. The dominant lithologies include conglomerate, sandstone, shale, limestone as well as volcaniclastics. The Vindhyan strata define a broad, regional syncline trending ENE-WSW. The axis of the syncline is slightly curved (convex towards north) and plunges gently towards west. The average dip of the southern limb is greater than that of the northern limb rendering the axial plane to dip southerly.

The Vindhyan succession can be divided into five major sequences separated by unconformities. The unconformities are manifested in the field by angular discordances and/or long-term subaerial exposure features. Unconformity surfaces are disposed in the succession defining what is known as progressive unconformity, indicating contemporaneous tectonic activity during sedimentation. Individual sequences comprise of a spectrum of depositional systems that include alluvial fan, fan delta, braidplain, braidplain delta, eolian sandsheet, siliciclastic/carbonate tidal flat, siliciclastic/carbonate shoreface, siliciclastic/carbonate shelf. The paleocurrents revealed by the Vindhyan strata are typically northerly suggesting that the evolving Satpura orogen served as the source for the Vindhyan sediments. However, the source for the clastics occurring within the Semri and the lower parts of the Kaimur and Rewa Groups in the Bundelkhand sector was perhaps the Bundelkhand Granite Gneiss, Bijawar and Gwalior Group of rocks as manifested by the southerly paleocurrent.

The sequences of the Vindhyan succession are composed of several systems tracts. The different paleogeographic settings characterizing the systems tracts within individual sequences are as follows:

\section{Sequence 1:}

- TST - alluvial fan-fan delta-shelf (Deoland and Arangi Formations)

- HST - carbonate ramp (Kajrahat Formation)

Keywords. Intracratonic basin; Proterozoic; depositional environments; sedimentation; sequence stratigraphy.

J. Earth Syst. Sci. 115, No. 1, February 2006, pp. 3-22

(C) Printed in India. 
Sequence 2:

- TST - shelf (Deonar Formation)

- FSST to TST - braid/fan delta-shelf (Koldaha Formation)

- HST - tidal flat-shoreface-shelf (Chorhat and Koldaha Formations)

- TST - shelf (Rampur Formation)

- TST - carbonate ramp (Rohtas Formation)

Sequence 3:

- TST - shoreface-shelf (Sasaram Formation)

- FSST - shoreface (Ghaghar Formation)

- TST - shelf (Bijaygarh Formation)

- HST - braidplain-braid delta-shelf (Mageswar and Dhandraul Formations)

Sequence 4:

- TST - shelf (Panna Formation)

- FSST to TST - shoreface (Assan and Jhri Formations)

- HST - braidplain-braid delta-shelf (Jhiri, Drammondgunj and Govindgarh Formations)

Sequence 5:

- TST - tidal flat (Ganurgarh Formation)

- HST - carbonate platform (Bhander Formartion)

- TST - tidal flat to coastal lagoon (Bundihill and Sirbu Formations)

- FSST - tidal flat-braidplain-eolian (Shikhaoda Formation)

\section{Intracratonic basin: An overview}

The middle to late Proterozoic was the period of development of intracratonic basins on the continental shields all over the world (Windley 1977; Condie 1989). The basin fills, often several kilometers thick, are typically unmetamorphosed, varyingly deformed sedimentary strata that got deposited in an unvegetated landscape. The strata lie unconformably on the Archean-early Proterozoic gneisses, high-grade rocks, granite-greenstones or metasedimentaries of Proterozoic mobile belts.

There are significant differences between Precambrian sedimentary deposits of intracratonic basin and their Phanerozoic-modern equivalents. For example, epeiric seas constitute an important depositional setting characterizing most of the Proterozoic intracratonic basins, but do not have any exact modern analogue (Friedman et al 1992; Eriksson et al 1998). Precambrian and some younger deposits sharing the features of modern tide-wave affected shoreface and shelf sediments have been ascribed as products of epeiric seas. These epeiric seas were much wider (hundreds of kilometers), and had a very low gradient with a maximum paleobathymetry around $100 \mathrm{~m}$ (Friedman et al 1992; Eriksson et al 1998). The basins, however, virtually lacked a discernible shelfslope break that characterizes present day continental margin shelf seas (Shaw 1964; Irwin 1965;
Schopf 1980; Friedman et al 1992; Aspler et al 1994; Runkel et al 1998).

Accumulation of a huge thickness of shallow water sediments in intracratonic basins clearly indicates synsedimentary subsidence. The driving forces of subsidence have remained unclear for many cratonic basins. Cratons are stable continental interiors or continental intraplate regions relatively free from tectonic effects, which are preferentially localized along their boundaries. However, intracontinental regions do experience intraplate stresses inducing subsidence and uplift though at much slower rates than that at plate boundaries (Park and Jaroszewski 1994). Traditionally cratonic basins have been thought to have suffered subsidence and uplift independently of the activities at the craton margin or plate boundary. Sediment loading, subcrustal loading and thermal subsidence have been considered to be the dominant mechanisms of subsidence in such basins. However, Sloss (1988a, b) pointed out that exclusion of cratons from the dynamics of plate tectonics is not a valid proposition and intraplate tectonic activities in many cases can be related to compressional or extensional events at the margin of the craton. In many basins, the subsidence is related to thermal contraction or subcrustal loading; these basins are typically oval in shape, and show symmetric isopach distribution (e.g., Illinois and Michigan basins, Angevine et al 1990). Subsidence induced by extensional tectonism has 


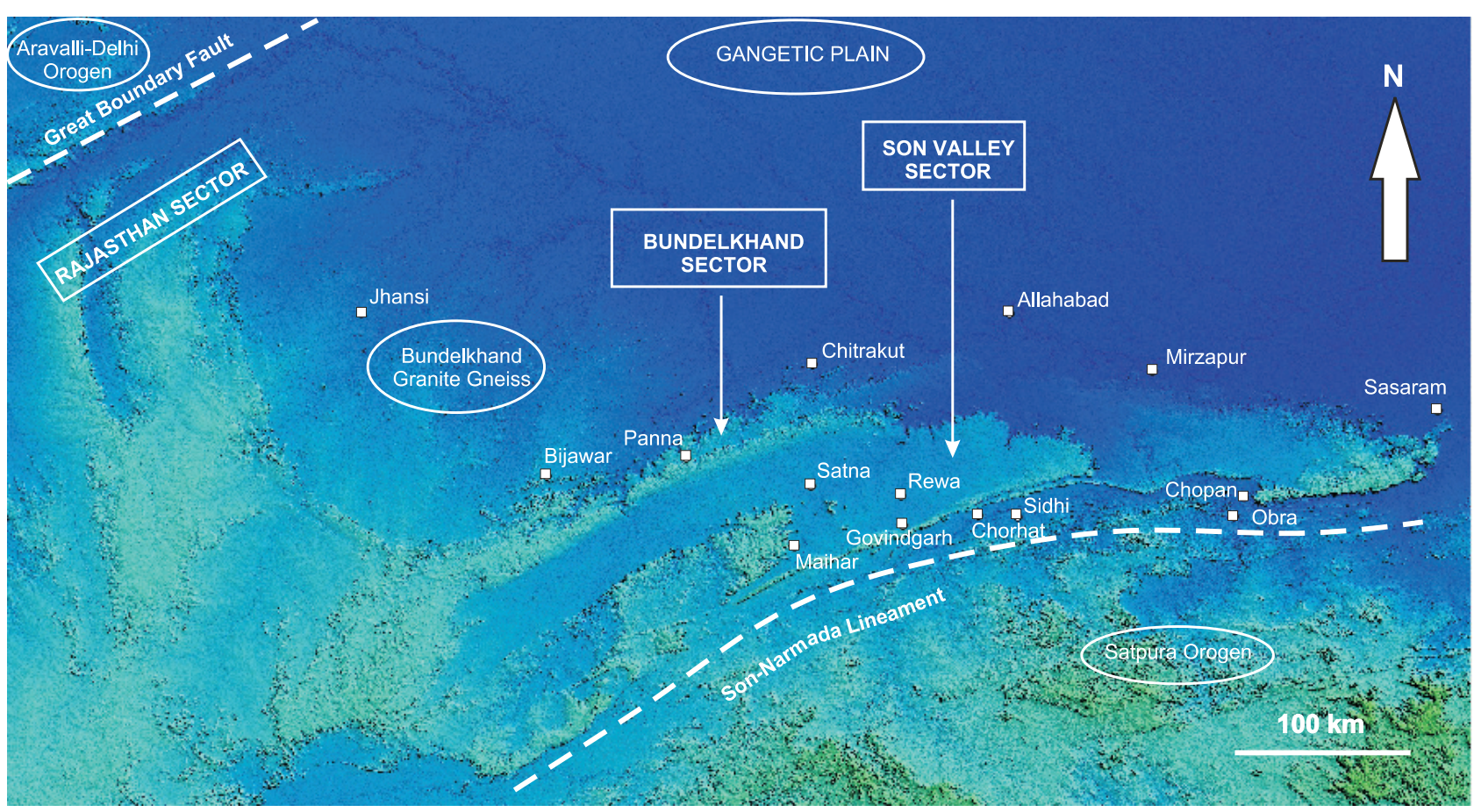

Figure 1. Outcrop of the Vindhyan basin as revealed by SRTM data. Note: (i) confinement of the basin between the Great Boundary Fault and the Son-Narmada lineament; (ii) occurrence of the Bundelkhand Gneiss at the middle of the basin; (iii) the Gangetic plain covering the northern part of the basin; (iv) occurrences of the Vindhyan strata in three different sectors - Rajasthan, Bundelkhand and Son valley. Locations of illustrative outcrops and sections are also shown.

been invoked for basins that are conspicuously narrow and linear (e.g., Pranhita-Godavari valley basin, Naqvi and Rogers 1987). The subsidence in basins located in front of Proterozoic mobile belts, on the other hand, has been thought to be due to supracrustal, thrust loading in the hinterland (Allen and Homewood 1986); the thickness of the basin fill in these basins systematically increases towards the orogenic front resulting in strongly asymmetric isopach distribution.

The Vindhyan basin of central India offers unique scope to resolve all these issues concerning the development and evolution of intracratonic basins during the Proterozoic. In the Indian shield, there are four large intracratonic basins of Proterozoic age:

1. Vindhyan basin,

2. Cuddapah basin,

3. Pranhita-Godavari basin, and

4. Chattisgarh basin barring the smaller Indravati, Kaladgi, Bhima and Badami basins.

Despite many differences in details, the sedimentaries developed in these widely separated basins display marked similarities in their lithology, depositional setting and stratigraphic architecture (Naqvi and Rogers 1987). This note summarises the stratigraphy, stratal architecture, sedimentology and geochronology of the Vindhyan
Supergroup occurring in the Son valley region (figure 1).

\section{The Vindhyan basin}

The Vindhyan strata are exposed in three sectors:

\section{Rajasthan sector}

2. Bundelkhand sector and

3. Son valley sector (figure 1).

In the west and south of the Vindhyan outcrop occur the fold-belts of Aravalli-Delhi and Satpura. At the central part of the basin occurs an isolated inlier of basement gneiss designated as the Bundelkhand massif. Along the southern edge of the Vindhyan outcrop and the eastern flank of the Bundelkhand massif are exposed a low-grade metamorphic group of volcano-sedimentary rocks, termed as the Mahakoshal Group and the Bijawar Group respectively. The northern part of the basin is hidden under the Gangetic alluvium (figure 1).

The southern margin of the Vindhyan basin is marked by a major ENE-WSW trending lineament termed Narmada-Son lineament south of which occurs the Satpura orogen (figure 1). The western margin of the Vindhyan basin in the Rajasthan sector is also marked by a NE-SW trending major lineament known as Great Boundary Fault separating 
STRIKE-WISE SECTION OF THE VINDHYAN SUCCESSION IN SON VALLEY

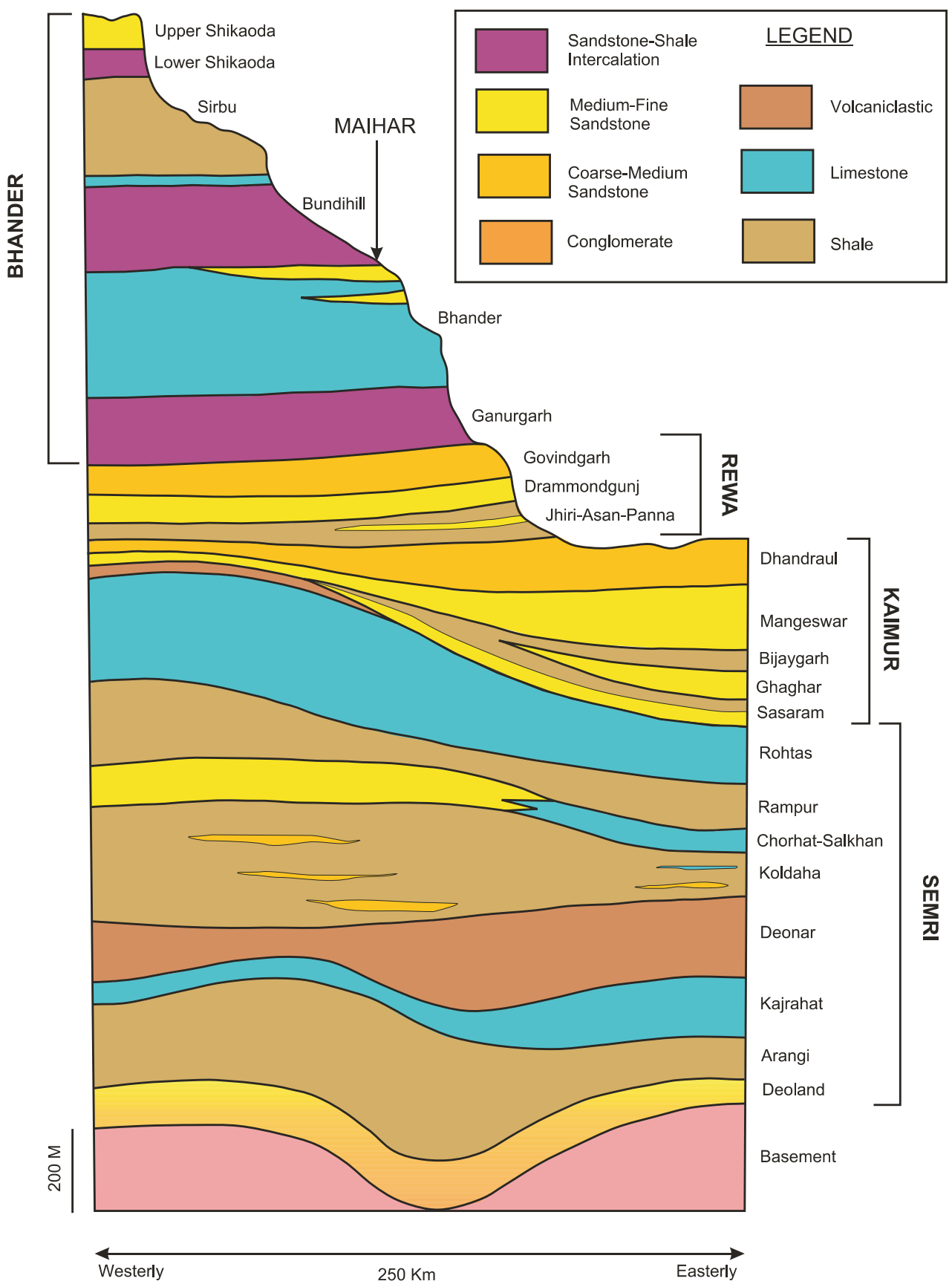

Figure 2. Strike-wise stratigraphic column of the Vindhyan Supergroup in the Son valley prepared by combining several discrete logs constructed at different locations along the structural strike. The upper boundary of the column represents the present-day topography. Maihar town has been shown as a reference location on the topographic profile.

the Aravalli-Delhi orogen from the Vindhyan (figure 1).

\subsection{Lithostratigraphy}

The entire Vindhyan succession, maximum thickness estimated to be around $3 \mathrm{~km}$, and comprising mainly sandstone, shale and limestone is assigned as the Vindhyan Supergroup (Bhattacharyya 1996). The Supergroup is divisible into four groups:

1. Semri Group,

2. Kaimur Group,

3. Rewa Group and

4. Bhander Group, 
from bottom to top (figure 2). Each group is again subdivided into several formations. An outline of the lithostratigraphy of the Vindhyan Supergroup of the Son valley is presented in table 1 (see also figure 2).

The Semri Group in the Son valley rests unconformably on a variety of pre-Vindhyan rocks such as granites and metamorphics. In the Bundelkhand area, the group overlies the Bundelkand Granite Gneisses and Bijawar Group of metamorphics, whereas in the southern Son valley, Mahakoshal is the basement in most places (figure 3A); however, in some localities (e.g., Deoland, M.P.) the basement is granite.

The Semri succession of the Bundelkhand area has two detached outcrops around Chitrakut and Bijawar respectively, and is only a few tens of meters thick (figure 1). The successions in these two outcrops are dissimilar. Moreover, these two successions have several dissimilarities with that of the southern Son valley:

- The succession in the Bundelkhand area is much thinner and dominated by carbonates, whereas in the southern Son valley both carbonates and siliciclastics are prevalent,

- The lithological attributes of the carbonates of the Bundelkhand area are quite different from that of the carbonates occurring in the southern Son valley,

- In the southern Son valley, volcaniclastic deposits form a major lithostratigraphic unit of the succession but are absent in the Bundelkhand area (Singh and Kumar 1978; Sastry and Moitra 1984).

The basal part of the Kaimur Group in the Bundelkhand area is represented by arkosic, pebbly sandstones and has no analogue in the Son valley. However, the overlying rocks are similar in the two regions.

The basal part of the Rewa Group occurring in the northern part of the Son valley is represented by conglomerates and arkosic sandstones, which have no equivalent in the southern part (Bose et al 1997). However, the overlying units are correlatable across the entire outcrop of the Vindhyans in the Son valley.

The field appearances of different formations are presented through a series of photographs (figures 3-6).

\section{Structural style of the Vindhyan strata}

The outcrop of the Vindhyan lithounits in the Son valley shows a parabolic pattern with easterly closure (figure 1). The northern arm has southerly dip, whereas the southern arm dips northerly with the basal units showing steep dips (figure 3A, B, C). This indicates a regional scale syncline with westerly plunge (figure 7 ). The trace of the axial plane is mildly curved with an overall ENE-WSW trend. In the Rajasthan sector near the Great Boundary Fault, the Vindhyan strata show tight and locally overturned folds trending parallel to the fault (Banerjee and Sinha 1981; Prasad 1984).

The geological profiles across the regional strike (ENE-WSW) in the Son valley (figure 8) revealed the presence of several sub-regional folds on the southern limb of the regional syncline (Chakraborty and Karmakar 1998). The different folds are recognizable in different stratigraphic units. However, integration of all the profiles leads to reconstruction of the overall structural pattern of the Vindhyan strata (figure 9). The salient features are:

- The cross-sectional geometry of the Vindhyan basin fill, normal to the regional strike, is asymmetric with the thickest part occurring towards south.

- The Vindhyan strata define a broad, regional syncline trending ENE-WSW. The axis of the syncline is slightly curved and plunges gently towards west. The average dip of the southern limb is greater than that of the northern limb rendering the axial plane to dip southerly.

- The preserved southern limb of the regional syncline shows two smaller, local anticlines intervened by two synclines. In contrast, the lowdipping northern limb is homoclinal $\left(<5^{\circ}\right)$.

- The smaller folds are asymmetric in nature with one limb longer and steeper (northern limb in case of anticlines and southern limb in case of synclines) than the other. Their axial planes dip southerly. In other words, the fold geometry is that of successive monoclines defining a terrace like or ramp-and-flat pattern.

\section{Stratal discontinuities in the Vindhyan succession}

The profiles constructed have also revealed the presence of angular discordances between different lithostratigraphic units of the Vindhyan succession at various levels (figure 9) as mentioned below.

- Between Kajrahat and Deonar Formations of the Semri Group.

- Between Rohtas Formation of the Semri Group and Sasaram Formation of the Kaimur Group. This is the most conspicuous unconformity surface within the Vindhayn succession.

- Between Dhandraul Formation of the Kaimur Group and Rewa Group. 


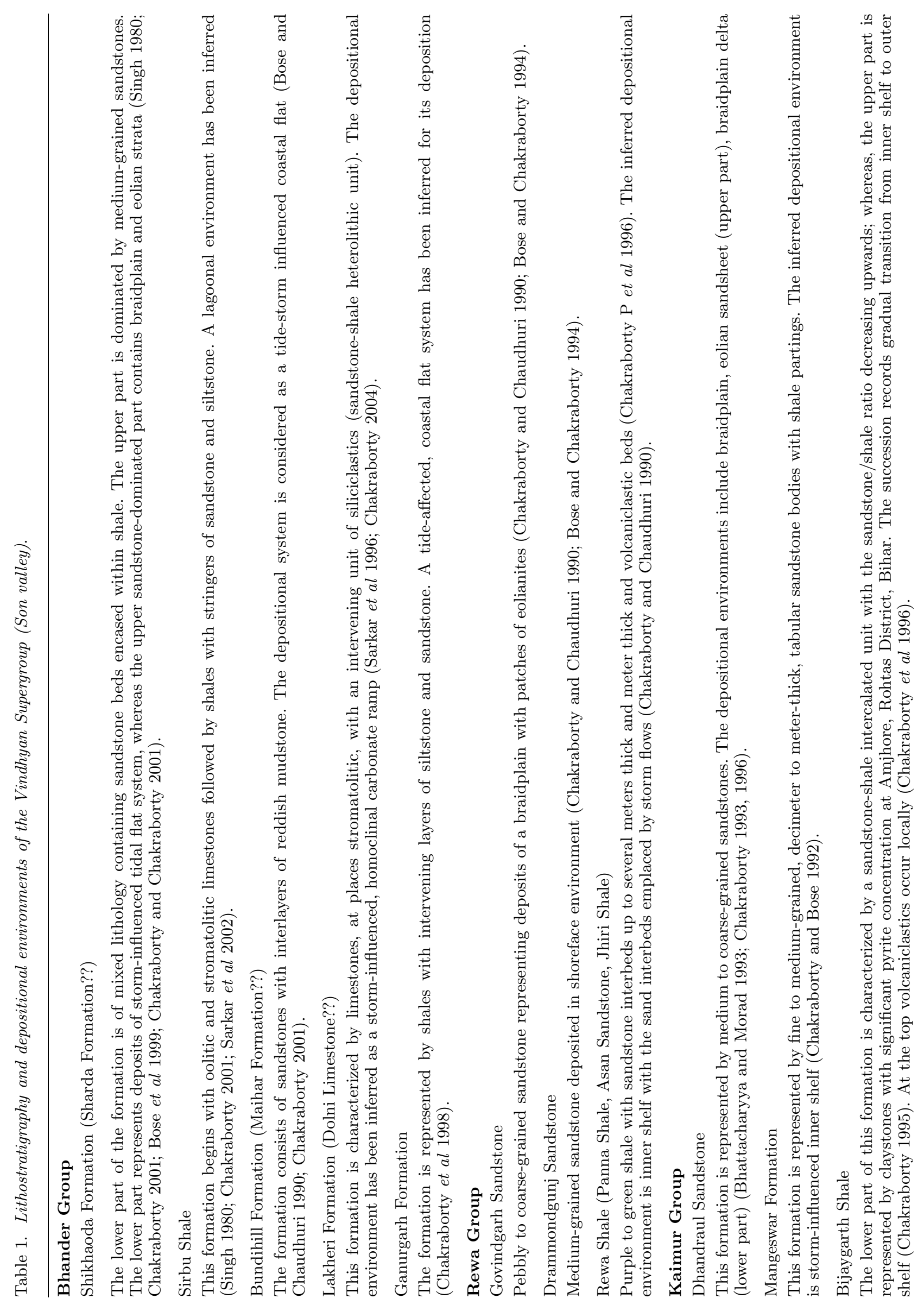




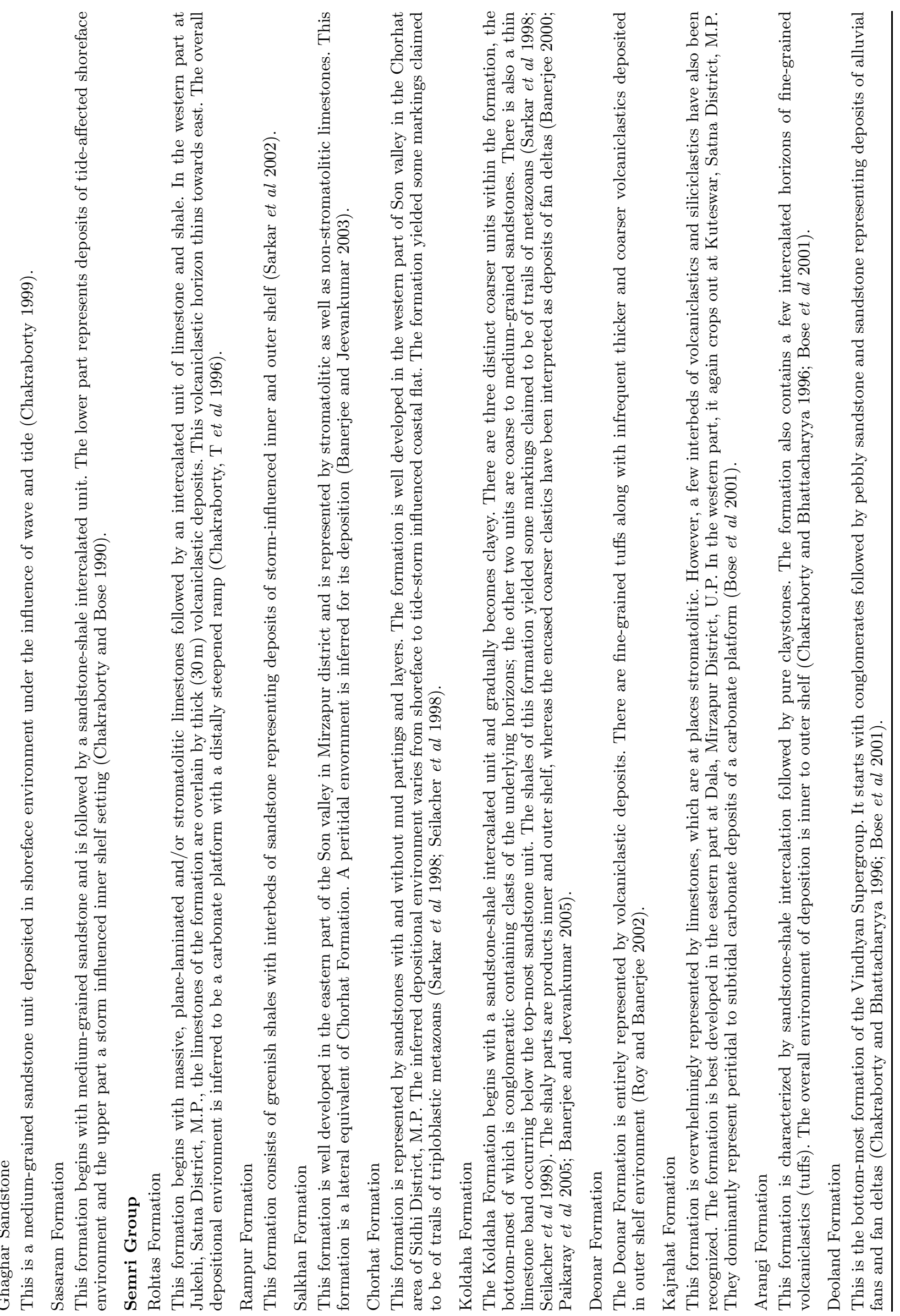



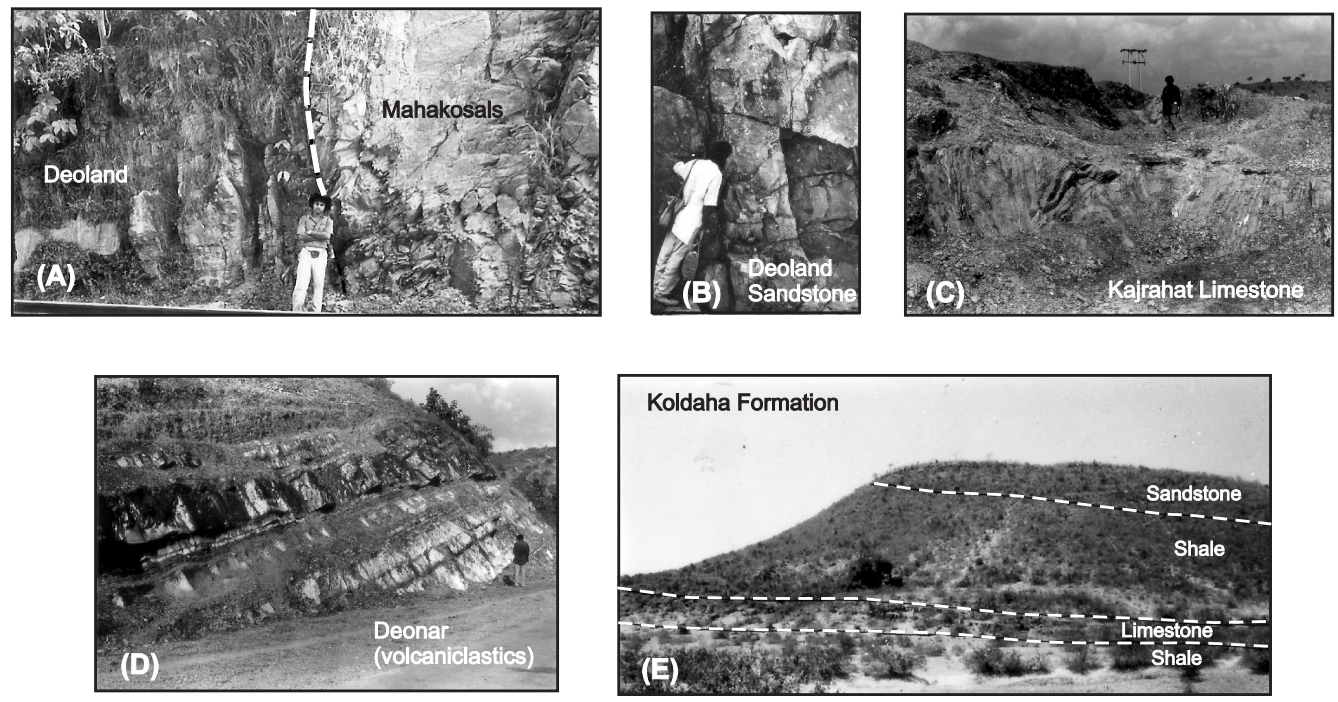

(F)

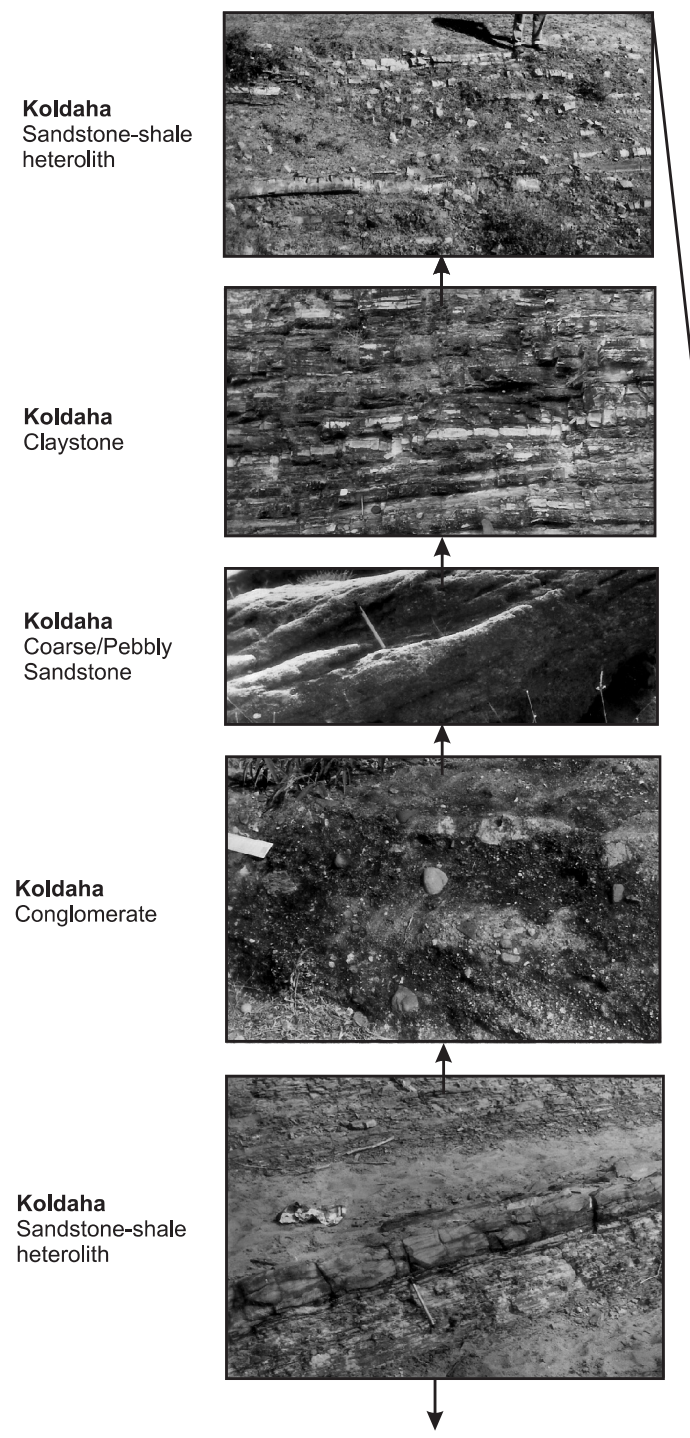

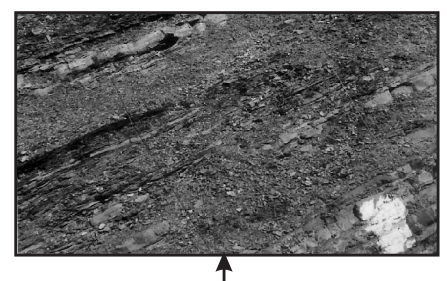

Mudstone-dominated Chorhat Formation

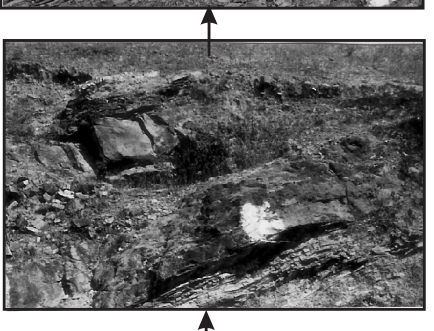

Sandstone-dominated Chorhat Formation

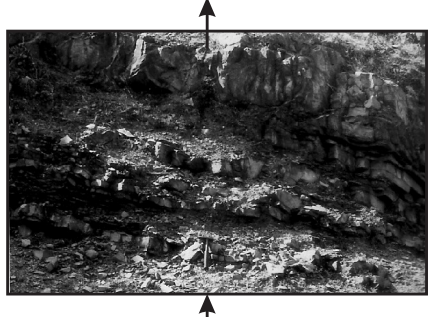

Koldaha

Sandstone-shale heterolith overlain by sandstone

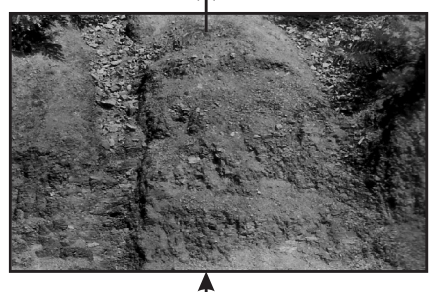

Koldaha

Claystone

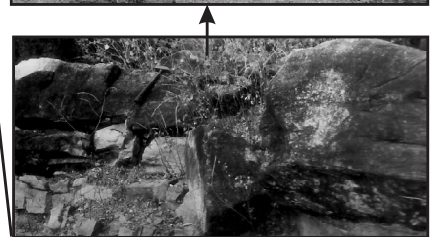

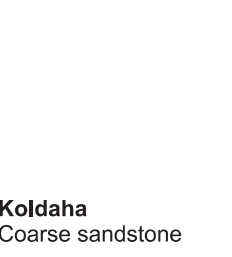

Coarse sandstone

Figure 3. Field appearances and vertical disposition of different stratigraphic units of the Semri Group in Son valley. Note: (i) steep dips of the Deoland Formation in A and B; (ii) tight, upright folds in the Kajrahat Limestone in C; (iii) dipping beds of Deonar Formation in D; (iv) vertical section through the Koldaha Formation in E; (v) vertical lithological variation within the Koldaha Formation in F. 

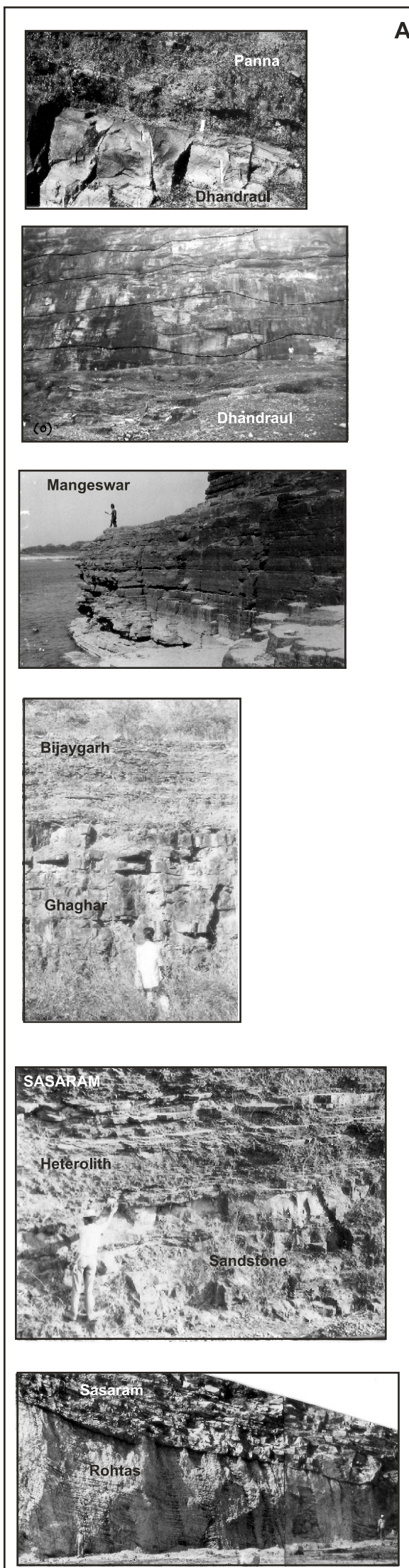

Rampur Shale

A
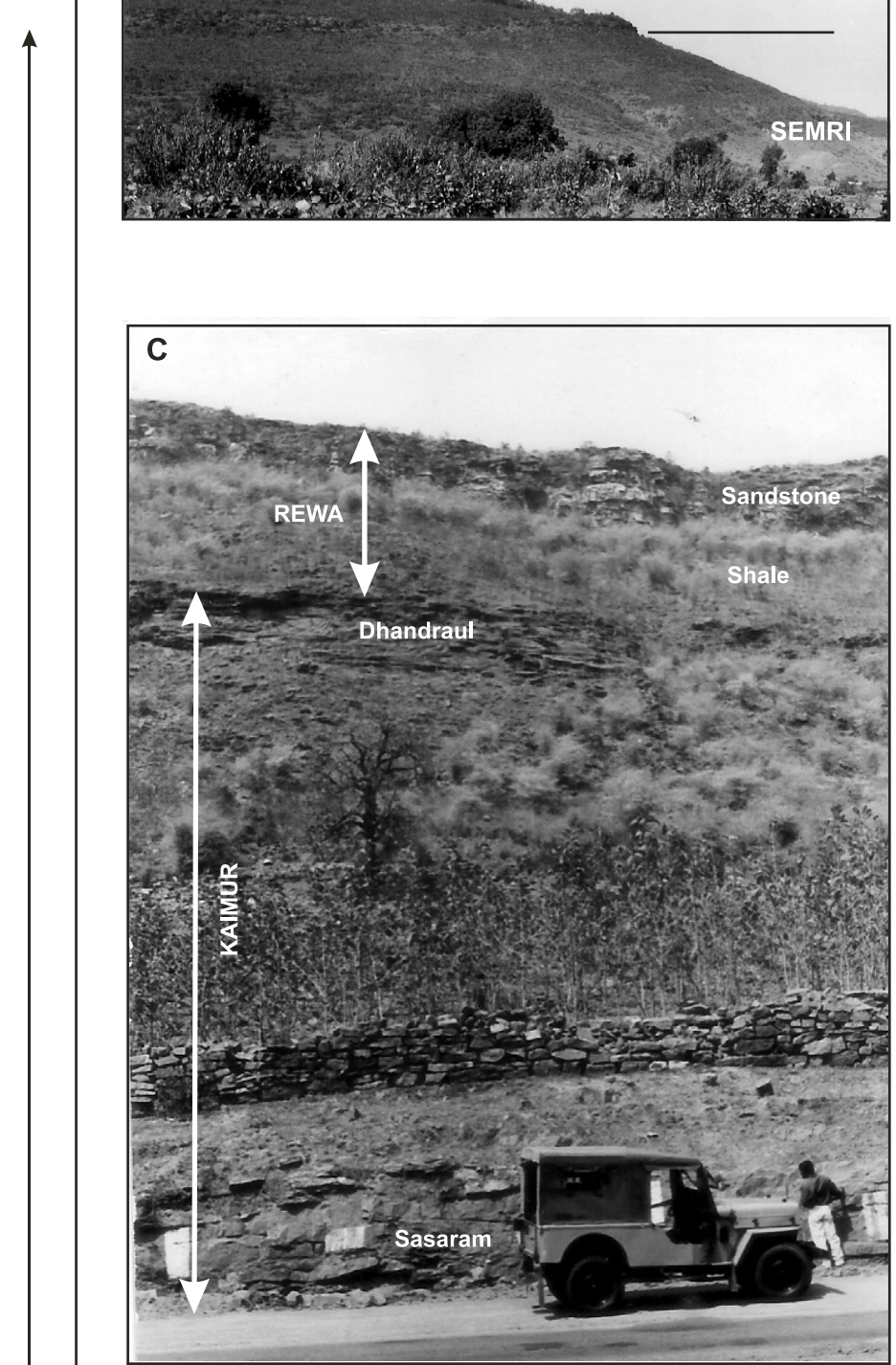

Figure 4. Field appearances and vertical disposition of different stratigraphic units of the Kaimur Group in the Son valley. Note: (i) Vertical succession of the Kaimur Group occurring between Rohtas Limestone of the Semri Group and Panna Shale of the Rewa Group in A. (ii) Continuous section of the whole Kaimur Group occurring above Semri Group in B and below Rewa Group in C. 


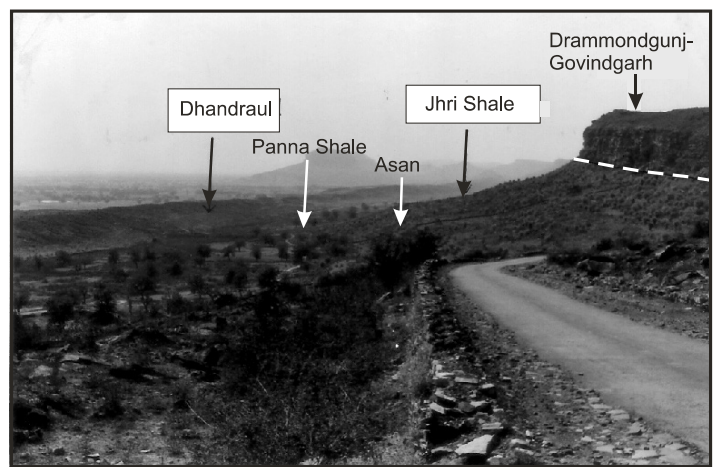

A

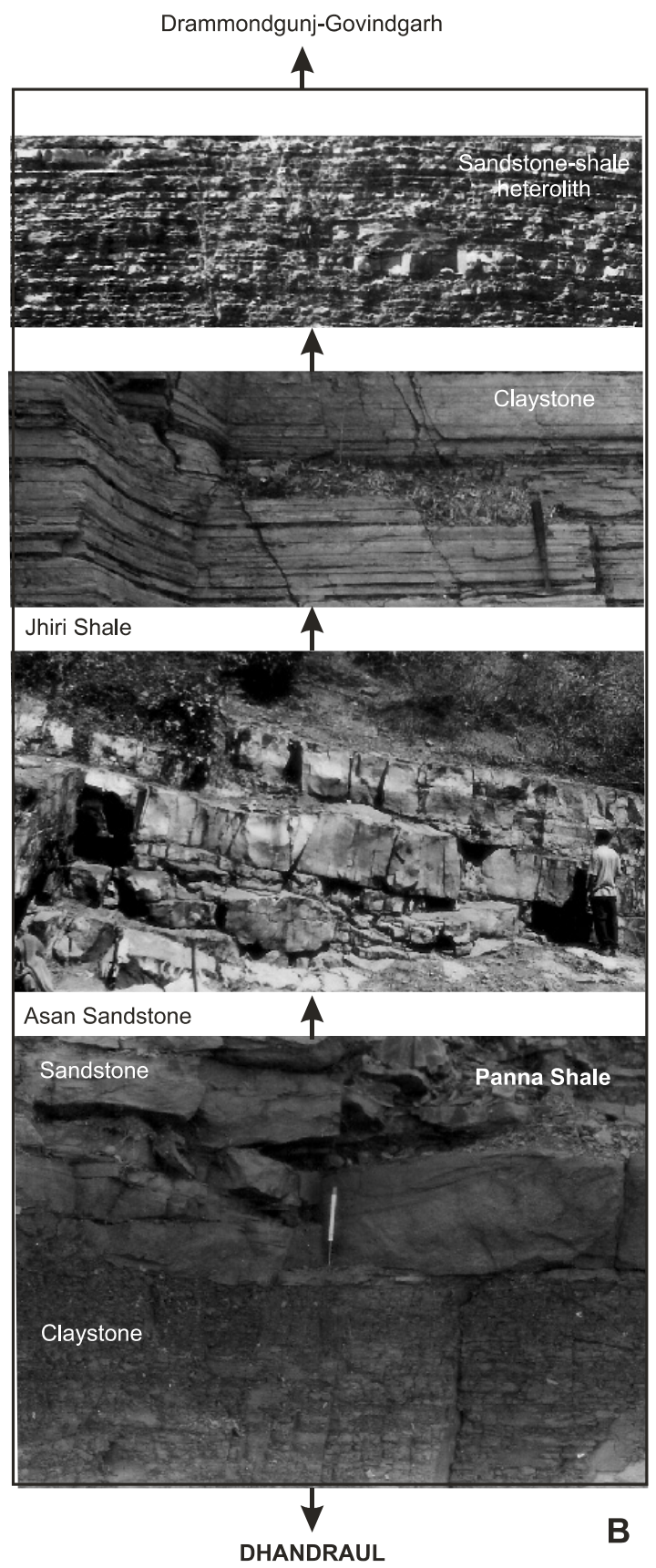

Figure 5. (A) Field appearance of the vertical transition from Dhandraul Sandstone (Kaimur Group) to the Rewa Group. (B) Vertical lithological variation within the Rewa Shale overlying the Kaimur Group.
- Between Govindgarh Formation of the Rewa Group and Ganurgarh Formation of the Bhander Group.

These angular discordances are recognizable in the south and they gradually grade into conformities, paraconformities or disconformities towards north.

Besides the angular unconformities, the stratal architecture is also suggestive of 'cumulative wedge systems' or 'progressive unconformities' indicating "a depositional surface which is tilted by uplift of one side and the subsidence of the other, with no interruption of sedimentation. Such features would be generated over an anticlinal flank and would especially well develop on the flanks of overfolds, overthrusts..." (Riba 1976).

It is, therefore, logical to infer that synsedimentary tectonism played an important role in the development of the Vindhyan succession and the deformation pattern shown by the Vindhyan strata was not a result of the post-Vindhyan tectonic event.

\section{Depositional systems}

In the Vindhyan succession many depositional systems have been recognized, the products of which occur at different stratigraphic levels, within different lithostratigraphic units (table 2).

\subsection{Description of depositional systems}

\section{1a Alluvial fan}

Lithosomes of gravity-flow dominated alluvial fan depositional system are characterized by disorganized, poorly-sorted breccias and conglomerates comprising angular to subangular fragments (1-20 cm long) of igneous and metamorphic rocks, vein quartz and jasper set in a matrix of coarse sand and granules. The content of matrix varies resulting in both clast-supported and matrixsupported texture. The sediment bodies are usually massive; however, at places crude layering defined by weakly oriented clasts may be observed. The grains of breccias at places show matching boundaries. Lithosomes are laterally impersistent and apparently appear to be lenticular in shape.

Lithosomes of stream-flow dominated alluvial fan depositional system are characterized by sediment bodies of conglomerates and pebbly to coarse grained sandstones. The conglomerates are moderately sorted, dominantly clast supported. Clasts are of metamorphic rocks, vein quartz, jasper, etc. and range in length from $10-15 \mathrm{~cm}$. The bodies may be massive, horizontally stratified or cross 

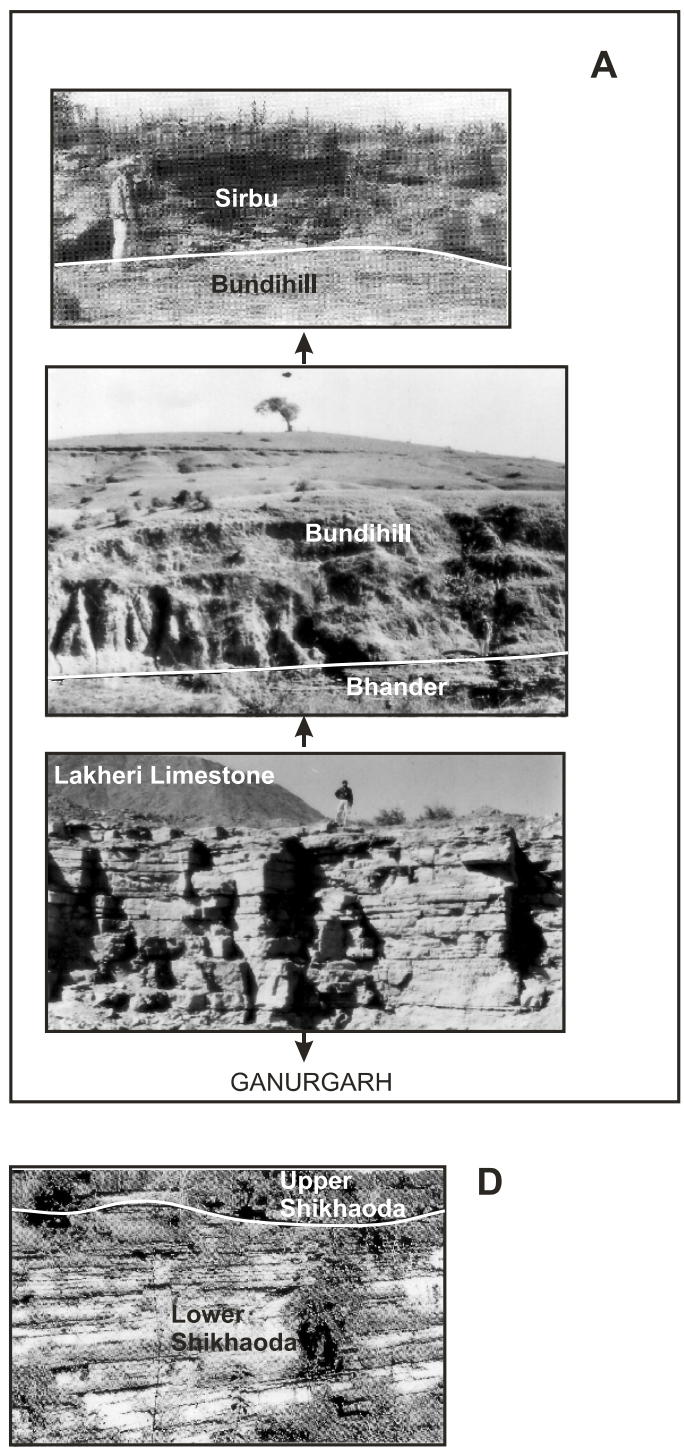

D

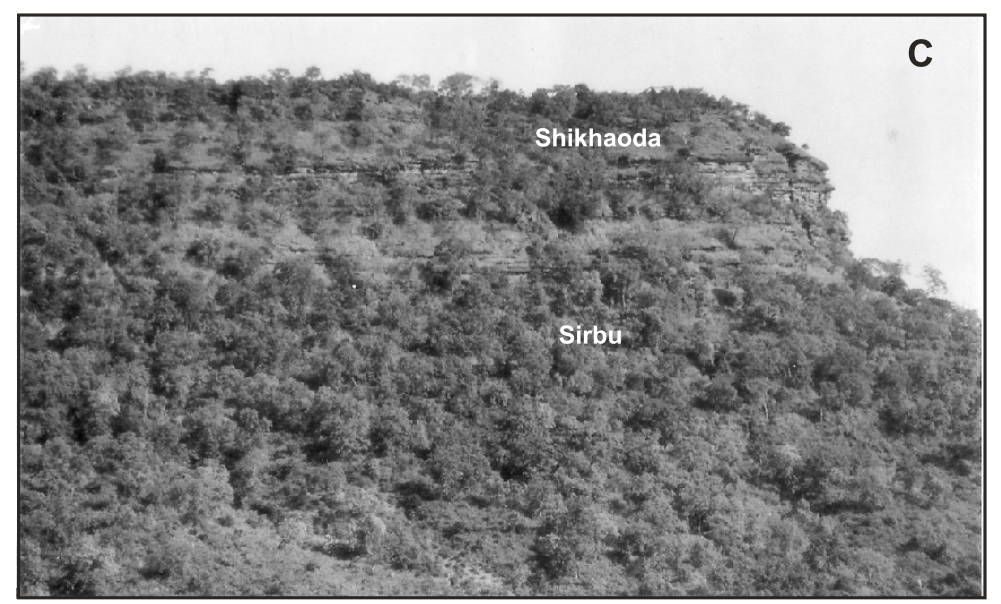

Figure 6. Field appearances of different stratigraphic units of the Bhander Group.

stratified. Channel cuts with stratified or massive fills are common. At places laterally extensive, graded (normal as well and reverse) beds have been observed.

\section{1b Fan delta}

Lithosomes of the fan delta plain depositional system are characterized by sheet-like, laterally extensive conglomerate beds with or without interbeds of granular sandstones. The clasts are poorly sorted, and mostly of vein quartz and jasper with a few fragments of basic and schistose rocks. The length of the clasts ranges from 1 to $15 \mathrm{~cm}$. They are dominantly subangular, supported by variable amounts of coarse sandy to granular matrix and are mostly unoriented; however, where the proportion of matrix is less they may be oriented with their long axis parallel to the bedding. The conglomerates are usually normally graded. The interbedded sandstones may be horizontally stratified, cross stratified or massive. At places, the system is represented by multistoreyed sandstones. The sandstones are cross stratified and often show preserved dunes of transitional flow regime.

Lithosomes of the delta front depositional system are characterized by parallel-sided beds of pebbly sandstones that become gradually pebblefree towards the top of the beds. The beds often show $\mathrm{T}_{\mathrm{abc}}$ type succession. The pebbles are subangular and dominantly of vein quartz and jasper and range in size from 0.5 to $5 \mathrm{~cm}$. There are also sandstone lithosomes with internal low-angle cross-stratification and with segregated pebble layers; on bedding planes wave ripples are common suggesting wave reworking of the delta front deposit. Pebble segregation can also be interpreted to be the result of wave reworking processes. 


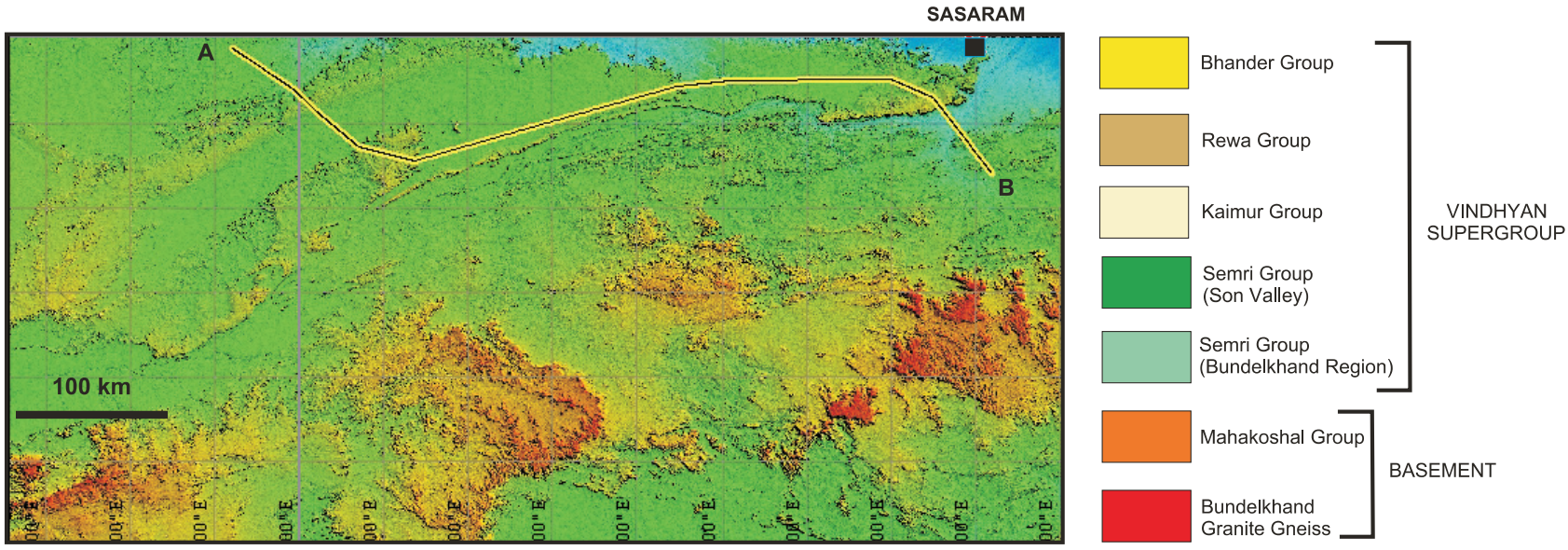

A

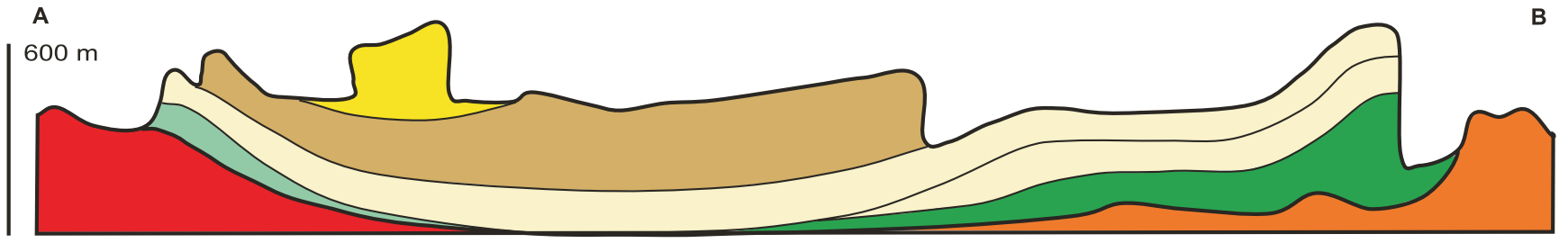

$125 \mathrm{~km}$

Figure 7. Sectional view of the Vindhyan Supergroup along the line A-B constructed from the DEM provided by SRTM and field observations. Note plateaus formed by the Semri, Kaimur, Rewa and Bhander Groups of rocks.

\section{1c Prodelta/shelf}

Lithosomes of the prodelta/shelf depositional system are represented by regular alternation between fine-to-medium grained sandstones and claystone. The sandstone beds are sharp based, parallel sided and show parting lineated parallel laminae.

\section{1d Braidplain and braid delta}

Lithosomes of braidplain depositional system are typically represented by vertically superimposed sheet-like, several meters thick sandstone bodies with little mudstones. The sandstone bodies have erosional lower contacts, at places replete with flutes, mud clasts and showing broad concaveupward geometry. Sandstones are dominantly medium grained; however, pebbly and gritty varieties are also common in some lithostratigraphic units. The sandstones are thoroughly cross stratified with trough, tabular and lenticular set geometry. The shape of cross-strata within a set may vary laterally from planar to concave-up to sigmoidal. The sigmoidal cross-sets often grades vertically into parallel-laminated units with parting lineation and current crescent. The cross-set thickness ranges between $30 \mathrm{~cm}$ and $70 \mathrm{~cm}$ and they show different types of reactivation surfaces. There are also solitary sets of planar cross-strata with a set thickness of more than a meter. Down current dipping cross-sets pertaining to 'foreset macroform' and small-scale channel fill sandstones have also been observed. Patches of eolianites characterized by adhesion ripples, translatent strata, along with rain prints are common.

The sandstone bodies show a systematic vertical distribution of sedimentary structures from cross-stratification to parallel-lamination suggesting deposition from flood events.

Lithosomes of braid delta depositional system share the features of braidplain depositional system. However, they are comparatively finer-grained and often show effects of reworking by wave and tide and altogether lack subaerial exposure features.

\section{1e Aeolian sandsheet}

Aeolian sandsheets have been recognized in the Dhandraul, Govindgarh and Shikhaoda Formations wherein they occur sandwiched between lithosomes of braidplain and coastal plain depositional system. The deposits include:

- sheet-like sandstones with internal translatent strata, capped by aeolian and adhesion ripples,

- sandstones internally showing adhesion ripple cross-lamination, 

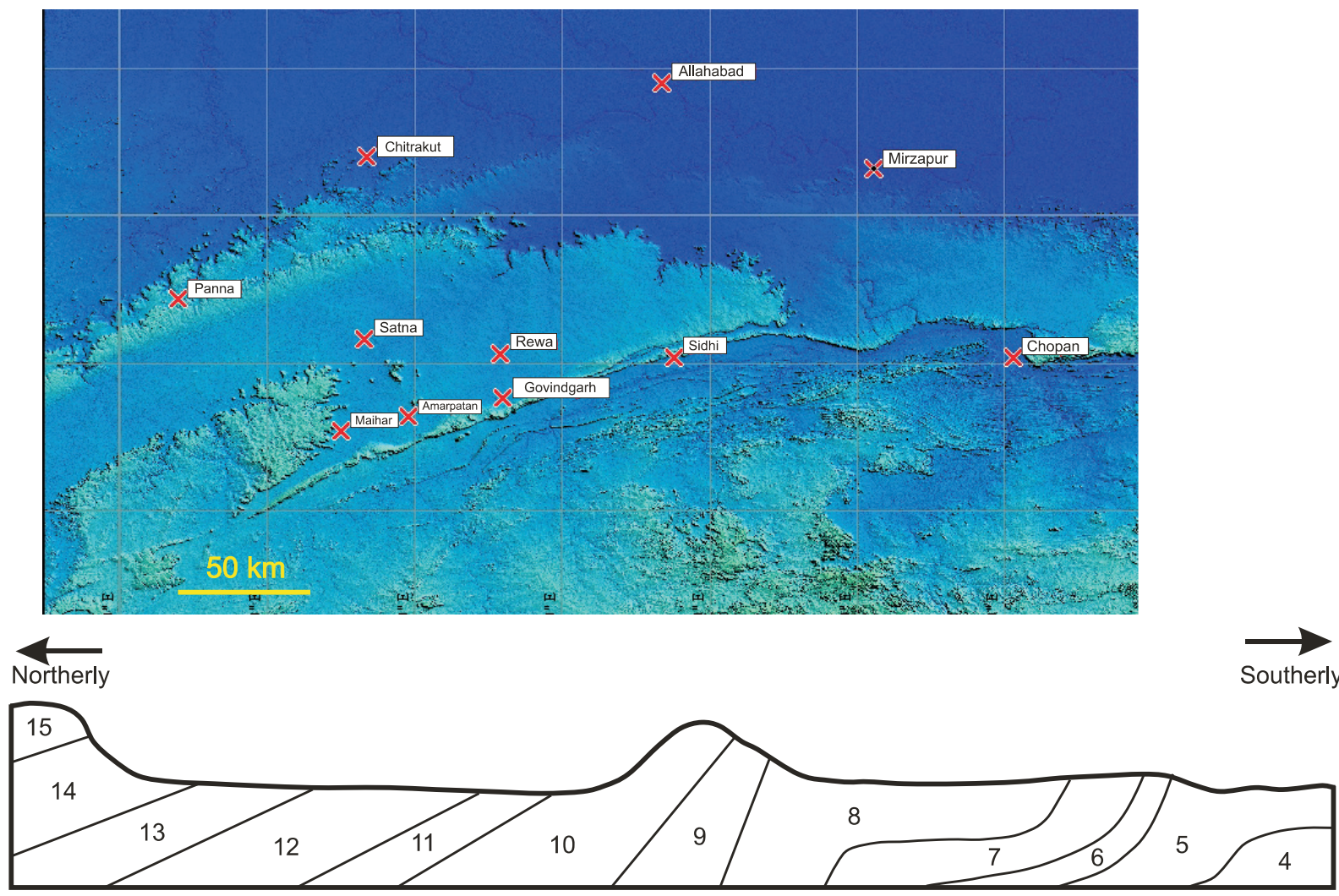

Downdip profile through Maihar

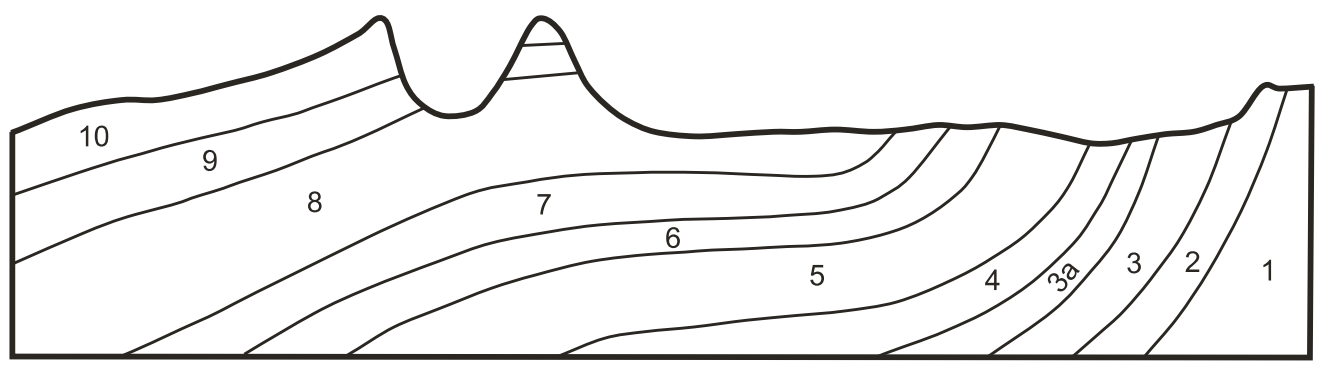

Downdip profile between Amarpatan \& Govindgarh

15. Shikaoda Fm.
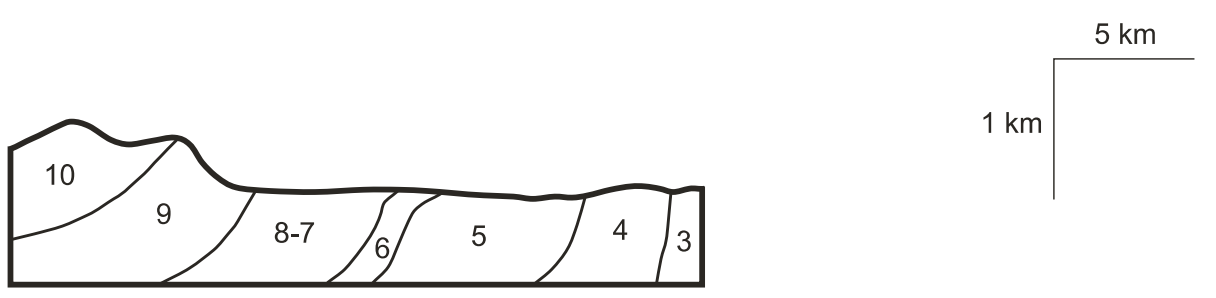

Downdip profile between Govindgarh \& Sidhi

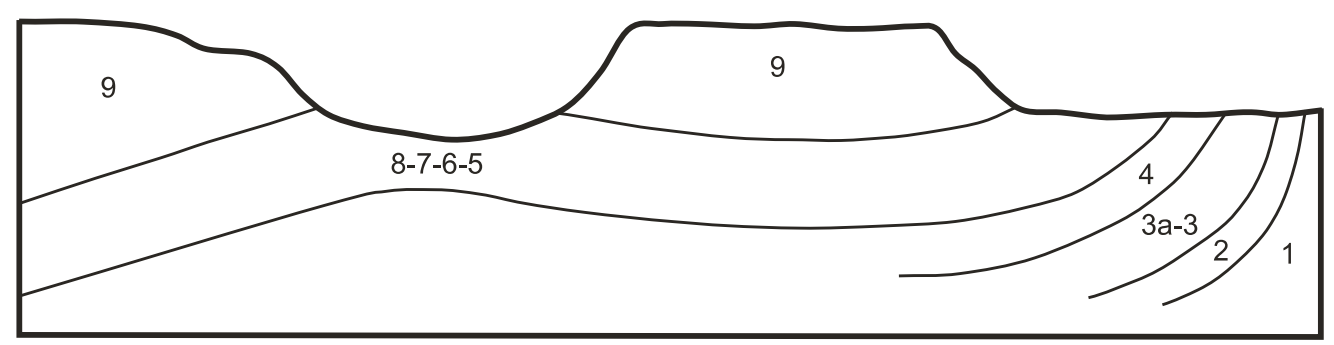

14. Sirbu Fm.

13. Bundihill Fm.

12. Lakheri Fm.

11. Ganurgarh Fm.

10. Rewa Group

9. Kaimur Group

8. Rohtas Fm.

7. Rampur Fm.

6. Chorhat/Salkhan

Fm.

5. Koldaha Fm.

4. Deonar Fm.

3a. Kajrahat Fm.

3. Arangi Fm.

2. Deoland Fm.

1. Basement

Downdip profile through Chopan

Figure 8. Downdip structural profiles of the Vindhyan succession in the Son valley. 


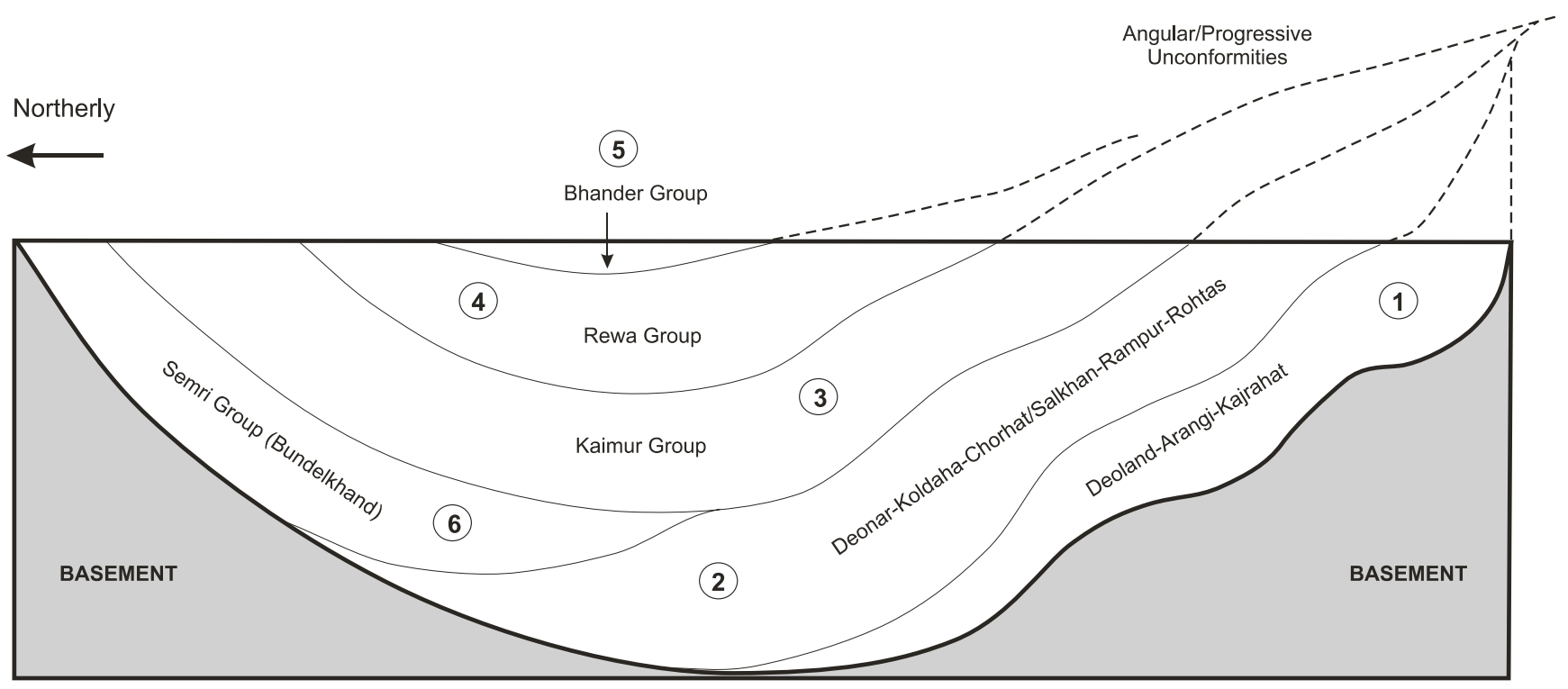

Figure 9. Inferred depositional sequences of the Vindhyan succession. Not to scale.

- lenticular sandstones showing cross-stratification characteristic of meter-scale longitudinal (seif) dunes, and

- lenticular sandstones with transverse aeolian dune cross-strata. The proportions of the last two types of lithosomes are much lower than the other types in the aeolian deposit.

\section{1f Siliciclastic tidal flat}

Upper tidal flat deposits include interlayered rippled-sandstones and mudstones with the sand:mud ratio varying widely resulting in lenticular bedding, wavy bedding, flaser bedding, etc. The lower tidal flat deposits are cross-stratified sandstones with little mud and the cross-strata are arranged in herring-bone pattern. The deposits are characterized by interference ripples, ladder-back ripples, flat-topped ripples, abundant rain prints, adhesion structures, desiccation cracks, mud clasts. Within the tidal deposits, there are also thicker sandstone beds (parallel and/or cross-laminated) showing sole marks, gutters, mud pebbles, etc. representing deposition from storm induced shooting flows on the tidal flat setting.

\section{1g Shoreface}

Shoreface deposits are represented by decimeter to meter thick sandstone beds with minor siltstones and claystones. Two types can be recognized: wave/storm dominated shoreface and tide-dominated shoreface.

Wave/storm dominated shoreface deposits show sharp based (often with sole marks), parallel-sided, cross-stratified sandstone beds grading upward into ripple bedded muddy sandstones. Cross-strata are dominantly low angle, planar to concave-up, unidirectional and anisotropic, hummocky. Ripples may be symmetric and asymmetric in profile with internal wave-diagnostic lamination. The features suggest deposition from sediment-laden combined flows induced by storms. The vertical variation in sedimentary structure and texture indicate dominance of unidirectional current component in the combined flow during the initial stage of deposition while oscillatory flow dominated the later phase of sedimentation. Amalgamation of beds is also common.

Tide-dominated shoreface deposits include sandstone beds showing compound cross-stratification characterized by horizontal and dipping cross-sets with the internal cross-strata arranged in herringbone pattern along with reactivation surfaces, mud drapes, mud clasts. The features suggest a shoreface surfaced by asymmetric dunes of tidal origin with superimposed smaller dunes.

\section{1h Inner shelf}

The indigenous deposits of inner shelf setting are muds. However, sands may be introduced by storm flows resulting in interbedded sandstone and mudstone. Storm deposited sandstone beds are sharp based with sole marks such as grooves, prods, flutes, gutters, etc. The beds deposited under the dominance of oscillatory component show hummocky cross-stratification and/or waveripple bedding grading vertically into the mudstone. Beds deposited under the dominance of unidirectional current are typically parallel sided with sole marks and internally show Bouma 
Table 1. Systems tracts of the Vindhyan Supergroup (Son valley).

\begin{tabular}{|c|c|c|}
\hline Depositional systems & Systems tracts & Formations \\
\hline \multicolumn{3}{|l|}{ Sequence 5} \\
\hline Braidplain, eolian, tidal flat & Falling stage & Shikhaoda \\
\hline Lagoon, tidal flat & Transgressive & Sirbu, Bundihill \\
\hline $\begin{array}{l}\text { Subtidal to peritidal } \\
\text { carbonate platform }\end{array}$ & Highstand & Bhander \\
\hline Tide-influenced coastal flat & Transgressive & Ganurgarh \\
\hline \multicolumn{3}{|l|}{ Sequence 4} \\
\hline $\begin{array}{l}\text { Outer to inner shelf to braid delta } \\
\text { to braidplain with eolian patches }\end{array}$ & Highstand & $\begin{array}{l}\text { Jhiri, Drammondgunj, } \\
\text { Govindgarh }\end{array}$ \\
\hline Shoreface & Falling stage & Asan \\
\hline Inner to outer shelf & Transgressive & Panna \\
\hline \multicolumn{3}{|l|}{ Sequence 3} \\
\hline $\begin{array}{l}\text { Inner shelf to braid delta to braid- } \\
\text { plain with eolian sandsheets }\end{array}$ & Highstand & Mangeswar, Dhandraul \\
\hline Inner to outer shelf & Transgressive & Bijaygarh \\
\hline Storm-tide influenced shoreface & Falling stage & Ghaghar \\
\hline Tide-influenced shoreface to shelf & Transgressive & Sasaram \\
\hline \multicolumn{3}{|l|}{ Sequence 2} \\
\hline Carbonate ramp & Transgressive & Rohtas \\
\hline Storm-influenced shelf & Transgressive & Rampur \\
\hline Shelf to shoreface to tidal flat & Highstand & Koldaha, Chorhat (Salkhan) \\
\hline Inner to outer shelf with fan delta & $\begin{array}{l}\text { Overall transgressive with } \\
\text { several intervening falling } \\
\text { stage packages }\end{array}$ & Deonar, Koldaha \\
\hline \multicolumn{3}{|l|}{ Sequence 1} \\
\hline $\begin{array}{l}\text { Subtidal to peritidal } \\
\text { carbonate platform }\end{array}$ & Highstand & Kajrahat \\
\hline Alluvial fan to fan delta to shelf & Transgressive & Deoland, Arangi \\
\hline
\end{tabular}

type sequences. Amalgamation of beds is also common.

\section{1i Outer shelf}

The deposits of outer shelf depositional system are typically mudstones with or without thin, parallel-sided layers of parallel laminated and/or micro cross-laminated fine sandstones deposited from storm suspensions with or without the influence of unidirectional current.

\section{1j Peritidal carbonates}

Peritidal carbonate deposits are characterized by intraclastic, flat pebble conglomerates, tepee structures, desiccation cracks, molar tooth structures, wavy or lenticular bedded limestones, microbial laminites, microdigitate or mini stromatolites (tufa), domal stromatolites, chert nodules and birds-eye structures.

\section{$5.1 \mathrm{k}$ Shallow subtidal carbonates}

Carbonates of shallow subtidal regime can be divided into two types:
1. Biohermal and

2. Clastic.

Biohermal carbonates show columnar stromatolites. Clastic carbonates show unidirectional (both high angle and low angle) as well as hummocky cross-stratification and horizontal stratification.

\section{$5.1 \ell$ Deep water carbonates}

Biohermal deep water carbonates are characterized by conical stromatolites. The other types of deposits include carbonate mud-encased suspension flow deposits characterized by massive carbonate conglomerates and calcareous sandstone beds showing vertical variation in structure from parallel lamination to ripple drift cross-lamination. The distal deposits are typically represented centimeter thick interlayers of limestone-shale rhythmites.

\section{Sequence stratigraphy}

The whole Vindhyan succession in the southern Son valley can be divided into five sequences separated by unconformities with one sequence in the 
Bundelkhand region (figure 9). The unconformities are manifested in the field by angular discordances and/or long-term subaerial exposure features. Each individual sequence again can be subdivided into several systems tracts represented in the succession as a sediment package defining a particular paleogeographic setting (table 2). The systems tracts are bounded by chronstratigraphically significant surfaces across which a change in paleogeographic setting can be inferred.

\subsection{Sequences of Vindhyan succession}

\section{1a Sequence 1}

Sequence 1 is represented by Deoland, Arangi and Kajrahat Formations (figures 2, 3A, B). It consists of two systems tracts (table 2). The lower tract reflects a paleogeography characterized by alluvial fan, fan delta and prodeltaic shelf and the systems are arranged in the succession retrogradationally defining what is known as transgressive systems tract (TST). The TST is followed by a sediment package representing the paleogeography of a carbonate platform - a homoclinal carbonate ramp. In this package, the deep-water carbonates are overlain by shallow subtidal carbonates with the peritidal carbonates occurring at the top. The stacking pattern indicates a highstand systems tract (HST). The boundary between the two systems tracts is, therefore, a maximum flooding surface.

The strata of the alluvial fan system mostly have high $\left(>50^{\circ}\right)$ dips. As a result, true paleocurrent directions could not be determined; however, the data suggest northerly transport of sediments with a source towards the south. The mean paleocurrent of the fan delta plain system is towards north, but the cross-strata azimuths show wide scatter (Bose et al 1997).

\section{1b Sequence 2}

Sequence 2 is represented by Deonar, Koldaha, Chorhat, Salkhan, Rampur and Rohtas Formations (figure 2). It consists of four major systems tracts (table 2). The first (from the bottom) systems tract is represented by the volcaniclastics of the Deonar Formation and claystones of the Koldaha Formation. The volcaniclastics and the claystones were deposited in shelfal water depths and the package shows a deepening-upwards trend defining a transgressive systems tract. However, this tract is often intervened by packages of coarser clastics (conglomerate, medium to coarse sandstone) deposited in shoreface region in the form of fan delta and braidplain delta representing falling stage systems tracts within the overall transgressive tract (figure $3 \mathrm{~F}$ ). The second systems tract represents a paleogeography characterized by tidal flat, shoreface and shelf depositional systems. Several parasequences could be recognized in this tract represented by progradational packages of shoreface to tidal flat strata and bounded by flooding surfaces. The parasequences show an aggradational to progradational stacking pattern. The systems tract is, therefore, a highstand systems tract consisting of upper parts of Koldaha Formation and Chorhat Formation (figure $3 \mathrm{~F}$ ).

The tidal flat deposits of the highstand systems tract are sharply overlain by shelf strata belonging to the Rampur Formation (figure 2). The upper bounding surface of the highstand systems tract may thus be interpreted as a transgressive surface representing a submarine discontinuity. The systems tract overlying the transgressive surface is represented by inner and outer shelf strata defining a deepening upwards trend and thus a transgressive systems tract. The top-most or the fourth systems tract of sequence 2 represents a paleogeography as a distally steepened carbonate ramp in which deposits of deeper systems occur upwards in the package. The tract is, therefore, a transgressive systems tract comprising the Rohtas Formation (figure 2).

Sequence 2 ends with a transgressive systems tract instead of a highstand systems tract. The upper bounding surface of the top-most TST of sequence 2 is a major unconformity surface of the Vindhyan succession delineating the Lower Vindhyan (Semri) from the Upper Vindhyan (figure 4A). In addition to angular discordances, this surface is also marked by long term subaerial exposure features, e.g., karstic dissolution, bauxitization, etc. Therefore, the absence of the HST could be due to erosional removal of the highstand strata.

The mean crestal trend of the wave ripples occurring in the shelf deposits of the second systems tract is along NW-SE. The cross-strata azimuths of the sandy braid delta systems of the same tract of the sequence indicates a mean paleocurrent towards NNW, whereas the mean paleocurrent indicated by the conglomerating fan delta systems is towards NE.

\section{1c Sequence 3}

Sequence 3 is represented by Sasaram, Ghaghar, Bijaygarh, Mangeswar and Dhandraul Formations of the Kaimur Group and consists of two systems tracts (figures 2 and 4 ). The lower systems tract reflects a paleogeography characterized by shoreface and shelf depositional systems (table 2). This tract contains several parasequences represented by progradational successions 
of tide-dominated shoreface to inner shelf strata, and each parasequence is bounded at the top by flooding surfaces. The parasequences are stacked retrogradationally. This set of retrogradational parasequences is topped by a regressive surface on which sharply occurs a parasequence defined by a progradational succession of storm-dominated shoreface strata which is bounded at the top by a flooding surface representing a falling stage deposit within the lower systems tract. The rest of the succession of the lower systems tract is represented by shelfal strata showing a deepening upwards trend. The lower systems tract, therefore, represents an overall transgressive tract with an intervening falling stage (regressive) wedge.

The upper systems tract represents a paleogeography characterized by braidplain, braid delta and shelf depositional systems arranged in progradational pattern defining a highstand systems tract. The boundary between the two systems tracts is, therefore, a maximum flooding surface.

In the TST, the azimuths of the cross-strata associated with tidal dunes reveal a bipolar, tri-modal distribution and indicate an average tidal flow along NE (ebb)-SW (flood) direction. The storm-generated cross-strata in the regressive wedge of the TST show wide divergence of azimuths, but a mean orientation towards north is indicated suggesting offshore transport of sediments. The wave ripples of the TST show wide scatter with a mean orientation along NNW-SSE. The sole marks occurring in the inner shelf deposits of the TST are typically oriented along NW-SE suggesting that the storm flow had along-shore components.

In the HST, the cross-strata/lamina of the inner shelf deposits shows a mean orientation towards NNW. The associated sole marks are dominantly oriented towards NW, although bipolar distribution is also common. The paleocurrent pattern of the braidplain and braid delta systems shows a mean sediment transport direction towards NNW.

\section{1d Sequence 4}

Sequence 4 is represented by Panna, Assan, Jhiri, Drammondgunj and Govindgarh Formations of the Rewa Group (figures 2 and 5). It consists of three systems tracts (table 2). The lower tract represents a paleogeography characterized by inner to outer shelf depositional systems. The tract is dominantly represented by shelfal strata with deepening upwards trend, i.e., a transgressive systems tract. This tract is sharply overlain by a package of shoreface strata bounded below by a regressive surface and above by a flooding surface (falling stage deposits). The uppermost systems tract is represented by braidplain, braid delta and shelf depositional systems arranged in progradational pattern defining a highstand systems tract. The boundary between the two systems tracts is evidently a maximum flooding surface.

In the braid delta system of the HST, the crossstrata azimuths show a wide scatter with a mean trend towards WNW, whereas the cross-strata of the braid-plain systems are more consistently oriented with a mean direction towards NNW.

\section{1e Sequence 5}

Sequence 5 is represented by Ganurgarh, Bhander, Bundihill, Sirbu and Shikhaoda Formations of the Bhander Group (figures 2 and 6). There are four systems tracts in the succession (table 2). The first tract is represented by siliciclastic tidal flat, presumably with a carbonate domain in the subtidal part. The systems are arranged in retrogradational pattern and thus define a transgressive systems tract. The second tract is represented by a homoclinal carbonate ramp with a progradational array of the depositional systems defining a highstand systems tract. The third tract reflects a paleogeography characteristic of siliciclastic, coastal lagoontidal flat depositional system overlain by marine strata representing a transgressive systems tract. The third tract is sharply overlain by coarser, proximal peritidal deposits and thus its top may be interpreted as a regressive surface. The fourth tract overlying the regressive surface is represented by strata reflecting progradation of a braidplain over the peritidal domain, i.e., a falling stage tract.

The cross-strata of the carbonate platform show a bipolar distribution along NE-SW with the stronger mode towards NE. The associated asymmetric ripples also reveal a mean migration direction towards NE, whereas the symmetric ripples have a mean crestal trend along NS.

The wave ripple trends in all the peritidal systems, although boxing the compass, reveal a mean trend along $140^{\circ}-320^{\circ}$. The asymmetric ripples in the Bundihill Formation show a mean orientation towards $35^{\circ}$, whereas the sole marks in the Sirbu Formation are grossly oriented along $71^{\circ}-249^{\circ}$. Only three flute cast orientations could be measured from the lower unit of the Shikhaoda Formation which indicate flows towards $215^{\circ}, 10^{\circ}$ and $357^{\circ}$. In Bundihill Formation sole mark orientations could not be measured due to exposure limitations. It is thus inferred that the gross orientation of the shoreline was NNW-SSW. The WNW directed paleocurrent of the fluvial deposit in the upper Shikhaoda Formation suggests that the land was located south of the inferred shoreline. The wind-induced currents operating in the peritidal 
flat thus appear to have had strong cross-shore components.

\subsection{Systems tracts at the Bundelkhand sector}

It has already been mentioned that there are sediment packages in the Vindhyan succession at the Bundelkhand region that, lithologically as well as in respect of paleocurrent, stand out from the depositional systems represented in the southern part of the Son valley. These packages should thus be considered as representing separate systems tracts and sequences from those of the southern Son valley.

The entire Semri Group of the northern part perhaps represents a sequence. Absence of volcaniclastics (represented by the widespread Deonar Formation in southern Son valley and Rajasthan) in this sequence suggests that the sequence postdates TST-1 of sequence 2 in the southern part. Interestingly, the paleocurrent data of this sequence demonstrate southerly transport of sediments from a northerly occurring source land.

There are two other sediment packages, at the base of the Kaimur and Rewa Groups, in the northern part standing apart from the depositional systems of the southern Son valley. These packages represent fan delta depositional systems prograding southerly from a northerly occurring scarp (Bose et al 1997).

\section{Summary}

- The features of the Vindhyan succession clearly indicate a vast intracratonic basin that remained within tens of meters of sea level throughout its lifetime. Apparently, shallow water condition was maintained over a large area for a long period of time suggesting that the sub-Vindhyan lithosphere suffered subsidence over a larger area producing a wide shallow ramp type basin. Hundreds of meters thick accumulation of peritidal strata in sequence 5 of the Vindhyan succession indicates that the subsidence rate was in perfect concert with the rate of sediment supply for a considerably long period of time during the end phase of Vindhyan basin evolution - the hallmark of cratonic basins Sloss (1988a, b). It is inferred that during the terminal period of the Vindhyan sedimentation a self-regulating system of uplift, erosion, sedimentation and subsidence controlled the accumulation of strata.

- The Vindhyan basin-fill in the Son valley exhibits an asymmetric cross-sectional geometry normal to the regional strike (ENE-WSW) with the thickest part occurring to the south.
- The Vindhyan strata define a broad, regional syncline trending ENE-WNW. The northern limb of the syncline is homoclinal and has low dip. In contrast, the southern limb is steeper and shows several sub-regional anticlines intervened by synclines arranged in a terrace-like (ramp and flat) fashion.

- In the southern part of the Son valley, the Vindhyan basin fill shows several angular unconformities that grade into conformities, paraconformities and/or disconformities towards north.

- The different depositional systems recognized in the Vindhyan succession are: alluvial fan, fan delta, braid delta, braidplain, eolian sand sheet, tidal flat (carbonate as well as siliciclastic), shoreface (tide and storm dominated), storm dominated shelf, homoclinal carbonate ramp, distally steepened carbonate ramp and epeiric peritidal flat (siliciclastic).

- The overall paleocurrent directions of the depositional systems in the Son valley are northerly suggesting a source towards south.

- The unconformities divide the Vindhyan succession of Son valley into five sequences. Each sequence consists of several systems tracts representing different paleogeographic settings and marking paleogeographic shifts.

- The different strata of the Vindhyan succession show evidences of soft-sediment deformation suggesting synsedimentary tectonic activity.

- The progressive and successive angular unconformities suggest that the deformation pattern shown by the Vindhyan strata is a reflection of synsedimentary tectonic activity.

- It is postulated that the individual sequences of the Vindhyan succession are related to discrete episodes of tectonism that induced the subsidence necessary for accumulation of sediments and resulted into deformation of the older strata. Angular unconformities resulted due to erosion of the uplifted crest of the anticlines on which the next sequence of strata was deposited with an angular discordance.

- There are sediment packages at the northern part of the Vindhyan basin developed from a northerly source and thus representing different tracts and sequences from those of the southern part. These packages are represented intermittently in the succession and have been interpreted as representing periods of uplift of the Bundelkhand Granite and subsequent erosion in the north.

\section{References}

Allen P A and Homewood P 1986 Foreland basins; Spec. Publ. 8 (Oxford: Blackwell Scientific Publications) 453p. 
Angevine C L, Heller P L and Paola C 1990 Quantitative sedimentary basin modelling; AAPG Continuing Education Course Note Series 32 p. 133.

Aspler L B, Chiarenzelli J R and Bursey T L 1994 Ripple marks in quartz arenites of the Hurwitz Group, northwest territories, Canada: evidence for sedimentation in a vast, early Proterozoic, shallow, fresh-water lake; J. Sed. Res. A64 282-298.

Banerjee A K and Sinha P N 1981 Structure and tectonics of Vindhyan in eastern Rajasthan; Misc. Publ. Geol. Surv. India 50 41-47.

Banerjee S and Jeevankumar S 2003 Facies motif and paleogeography of Kheinjua Formation, Vindhyan Supergroup, eastern Son valley; Gondwana Geological Magazine, Special Volume 7 363-370.

Banerjee S and Jeevankumar S 2005 Microbially originated wrinkle structures on sandstone and their stratigraphic context: Paleoproterozoic Koldaha Shale, central India; Sedim. Geol. 176 211-224.

Banerjee S 2000 Climatic versus tectonic control on storm cyclicity in Mesoproterozoic Koldaha Shale, central India; Gond. Res. 3 521-528.

Bhattacharyya A (ed.) 1996 Recent advances in Vindhyan geology; Geol. Soc. India Memoir 36 p. 331.

Bhattacharyya A and Morad S 1993 Proterozoic braided ephemeral fluvial deposits: an example from the Dhandraul Sandstone Formation of the Kaimur Group, Son valley, India; Sedim. Geol. 84 101-114.

Bose P K and Chaudhuri A K 1990 Tide versus storm in epeiric coastal deposition: two Proterozoic sequences, India; Geological Journal 25 81-100.

Bose P K and Chakroborty P P 1994 Marine to Fluvial transition: Proterozoic Upper Rewa sandstone, Maihar, India; Sedim. Geol. 89 285-302.

Bose P K, Banerjee S and Sarkar S 1997 Slope-controlled seismic deformation and tectonic framework of deposition of Koldaha Shale, India; Tectonophysics 269 151-169.

Bose P K, Chakraborty S and Sarkar S 1999 Recognition of ancient aeolian longitudinal dunes: a case study from the Upper Bhander sandstone, Son valley, India; J. Sedim. Res. 69 86-95.

Bose P K, Sarkar S, Chakraborty S and Banerjee S 2001 Overview of the Meso- to Neoproterozoic evolution of the Vindhyan basin, central India (1.4-0.55 Ga); Sedim. Geol. $141395-419$

Chakraborty C 1993 Morphology, internal structure and mechanics of small longitudinal (seif) dunes in an aeolian horizon of Proterozoic Dhandraul Quartzite, India; Sedimentology 40 79-85.

Chakraborty C 1995 Gutter casts from the Proterozoic Bijaygarh Shale Formation, India: their implication for storm-induced circulation in shelf settings; Geological Journal 30 69-78.

Chakraborty C 1996 Sedimentary records of erg development over a braidplain: Proterozoic Dhandraul Sandstone; Mem. Geol. Soc. India 36 77-99.

Chakraborty C 1999 Forced regressive shoreface deposits: Proterozoic Ghaghar Formation, Vindhyan Supergroup, Son valley; Indian Journal of Geology 71 265-275.

Chakraborty C 2001 Lagoon-tidal flat sedimentation in an epeiric sea: Proterozoic Bhander Group, Son valley, India; Geological Journal 36 125-141.

Chakraborty C and Bose P K 1990 Internal structures of sandwave in a tide-storm interactive system: Proterozoic Lower Quartzite Formation, India; Sedim. Geol. 67 133-142.

Chakraborty C and Bose P K 1992 Rhythmic shelf storm beds: Proterozoic Kaimur Formtion, India; Sedim. Geol. 77 259-268.
Chakraborty C and Bhattacharyya A 1996 Fan delta sedimentation in a foreland moat: Deoloand Formation; Geol. Soc. India Memoir 36 27-48.

Chakraborty C and Karmakar S 1998 Structural architecture of Vindhyan strata in Son valley: implications for basin tectonics; J. Geol. Soc. India $\mathbf{5 1}$ 377-382.

Chakraborty P P 2004 Facies architecture and sequence development in a Neoproterozoic carbonate ramp: Lakheri Limestone, Member, Vindhyan Supergroup, Central India; Precam. Res. 132 29-53.

Chakraborty P P, Sarkar S and Bose P K 1998 A viewpoint on intracratonic chenier evolution: clue from a reappraisal of the Proterozoic Ganurgarh Shale, central India; In: The Indian Precambrians (ed.) Palliwal B S (Jodhpur: Scientific Publishers, India) pp. 61-72.

Chakraborty P P, Sarkar S, Banerjee S, Das N G and Bose P K 1996 Volcaniclastics and their sedimentological bearing in Proterozoic Kaimur and Rewa Groups; Geol. Soc. India Memoir 36 59-75.

Chakraborty T and Chaudhuri A K 1990 Stratigraphy of the late Proterozoic Rewa Group and palaeogeography of the Vindhyan basin in central India during Rewa sedimentation; J. Geol. Soc. India 36 383-402.

Chakraborty T and Chakraborty C 2001 Eolian and aqueous interactions in the development of a Proterozoic sand sheet: Shikhaoda Formation, Bhopal, India; J. Sedim. Res. 71 106-115.

Chakraborty T, Sarkar S, Chaudhuri A and Dasgupta S 1996 Depositional environments of Vindhyan and other Purana basins: a reappraisal in the light of recent findings; Geol. Soc. India Memoir $\mathbf{3 6}$ 101-126.

Condie K C 1989 Plate tectonics and crustal evolution (New York: Pergamon) p. 476.

Eriksson P G, Condie K C, Tirsgaard H, Mueller W U, Altermann W, Miall A D, Aspler L B, Catuneanu O and Chiarenzelli J R 1998 Precambrian clastic sedimentation systems; Sedim. Geol. 120 5-53.

Friedman G M, Sanders J E and Kopaska-Merkel D C 1992 Principles of sedimentary deposits (New York: Macmillan) p. 717.

Irwin M L 1965 General theory of epeiric clear water sedimentation; AAPG Bull 49 445-459.

Naqvi S M and Rogers J J W 1987 Precambrian geology of India (Oxford: Clarendon Press) p. 223.

Paikaray S, Banerjee S and Mukherji S 2005 Facies analysis of the Koldaha Shale, Vindhyan Supergroup and its paleogeographic implications; Ind. J. Petrol. Geol. 13(2) $1-11$.

Park R G and Jaroszewski W 1994 Craton, tectonics, seismicity; In: Continental deformation (ed.) P L Hancock (Oxford: Pergamon) p. 222.

Prasad B 1984 Geology, sedimentation and paleogeography of the Vindhyan Supergroup, SE Rajasthan; Geol. Surv. India Memoir 116(1) 1-102.

Riba O 1976 Sytectonic unconformties of the Alto Cardener, Spanish Pyrenees, a genetic interpretation; Sedim. Geol. 15 213-233.

Roy S and Banerjee S 2002 Facies and petrography of the Porcellanite Formation around Chopan, Uttar Pradesh; J. Ind. Assoc. Sedim. 20 195-205.

Runkel A C, McKay R M and Palmer A R 1998 Origin of a classic cratonic sheet sandstone: stratigraphy across the Sauk II-Sauk III boundary in the Upper Mississippi valley; GSA Bull. 110 188-210.

Sarkar S, Banerjee S and Bose P K 1998 Trace fossils in the Mesoproterozoic Koldaha Shale, Central India, and their implications; N. Jb. Paleont. Mh. 7 425-438. 
Sarkar S, Chakraborty P P and Bose P K 1996 Proterozoic Lakheri Limestone, central India: facies, paleogeography, and paleophysiography; Geol. Soc. India Memoir $\mathbf{3 6}$ $5-26$.

Sarkar S, Chakraborty S, Banerjee S and Bose $\mathrm{P}$ K 2002 Facies sequence and occult imprint of sag tectonics in Sirbu Shale; Spec. Publ. Int. Assoc. Sed. 33 369-381.

Sarkar S, Banerjee S, Chakraborty S and Bose P K 2002 Shelf storm flow dynamics: insight from the Mesoproterozoic Rampur Shale, central India; Sedim. Geol. 147 89-104.

Sastry M V A and Moitra A K 1984 Vindhyan stratigraphy a review; Geol. Surv. India Memoir 116 109-148.

Schopf T J M 1980 Oaleoceanography (Cambridge, MA: Harvard University Press).

Shaw A B 1964 Time in stratigraphy (New York: McGraw-Hill).
Seilacher A, Bose P K and Pflueger F 1998 Triploblastic animals more than 1 billion years ago: trace fossil evidence from India; Science 282 80-83.

Singh I B and Kumar S 1978 On the stratigraphy and sedimentation of the Vindhyan sediments in the Chitrakut area, Banda District (U.P.)-Satana District (M.P.); J. Geol. Soc. India 8 359-367.

Singh I B 1980 Precambrian sedimentary sequences of India: their peculiarities and comparison with modern sediments; Precamb. Res. 12 411-436.

Sloss L L 1988a Introduction; In: Sedimentary cover - North American craton. The Geology of North America (ed.) Sloss L L, p. D-2, 1-3.

Sloss L L 1988b Conclusions; In: Sedimentary cover - North American craton. The Geology of North America (ed.) Sloss L L, p. D-2, 493-496.

Windley B F 1977 Evolving cotinents (London: John Wiley \& Sons) p. 385. 